\title{
Wind Energy Fed UPQC System for Power Quality Improvement
}

\author{
Sarita Samal, Prakash Kumar Hota
}

Department of Electrical Engg, VSSUT, Burla, Odisha, India

\begin{abstract}
The extensive use of non-linear loads in domestic, industrialand commercial services origin harmonic complications.Harmonics make malfunctions in profound equipment, voltage drop across the network, conductor heat increases and overvoltage through resonance. All these problems can be remunerated by using Unified Power Quality Controller (UPQC) and the operation of UPQC depends upon the available voltage across capacitor present in dc link. If the capacitor voltage is maintained constant then it gives satisfactory performance. The proposed research is basically on designing of Wind energy fed to the dc link capacitor of UPQCso as to maintain propervoltageacross it and operate the UPQC for power quality analysis. The proposed technique is the grouping of shunt and series Active Power Filter (APF) to form UPQC which is fed wind energy system and connected to grid for better response in the output. In this paper, the simulation model of series APF, shunt APF, UPQC and Wind energy with UPQC are design in Matlab. The proposed Wind energy-UPQC is design in Matlab simulation for reduction of voltage sag, swell, harmonics in load current and compensation of active and reactive power.
\end{abstract}

Copyright $\left({ }_{0} 2018\right.$ Institute of Advanced Engineering and Science. All rights reserved.

\section{Corresponding Author:}

Sarita Samal,

Department of Electrical Engg, VSSUT, Burla, Odisha, India.

Email: saritaruchy@gmail.com

\section{INTRODUCTION}

In power system, the word harmonic is extensively used to define the distortion for voltage or current waveforms. Harmonic related problems occur due to nonlinear loads. These non-linear loads take only short pulses of current from source and combine with the source impedance resulting in distortion of the supply voltage. Moreover, the use of electricity is increasing very rapidly so the necessity of renewable energy based source is required for interconnection to the distribution network The main drawbacks of the renewable sources are the power generation is not continuous and it is season based. To overcome these disadvantages numbers of renewable sources are interconnected [1-2]. However, for maintaining the power quality difficulty power electronics switches with advance controller mechanism are used [3]. The theory, modeling and application of a unified power quality conditioner has been described by Chen et al [4]. Basu et al [5] have made a comparative evaluation of two models of UPQC for suitable interface to enhance power quality. Montero et al [6] have developed number of method for shunt active power filters used in threephase system. Lee et al [7] described the control techniques of series active power filters compensating for source voltage unbalance and current harmonics. An efficient voltage sag recognition procedure for a dynamic voltage restorer has been developed by Fitzer et al [8]. The simulation and experimental design of shunt active power filter for harmonics and reactive power compensation have been described by Jain et al [9]. 


\section{WIND ENERGY FED UPQC SYSTEM}

This paper presents the design and development of the proposed wind energy fed UPQC system. By using instantaneous d-q control theory techniques along with PI and hysteresis band controller, the mitigation of voltage sag and swell under different balance and unbalanced load conditions are simulated. The use of wind energy for retaining fixed DC link voltage is another distinguishing feature of the wind energy-UPQC system. The proposed configuration with UPQC is shown in Figure 1, where voltage sag/swell reimbursement and active power injection to the Point of Common Coupling (PCC) in addition to the other regular UPQCoperation can be achieved.

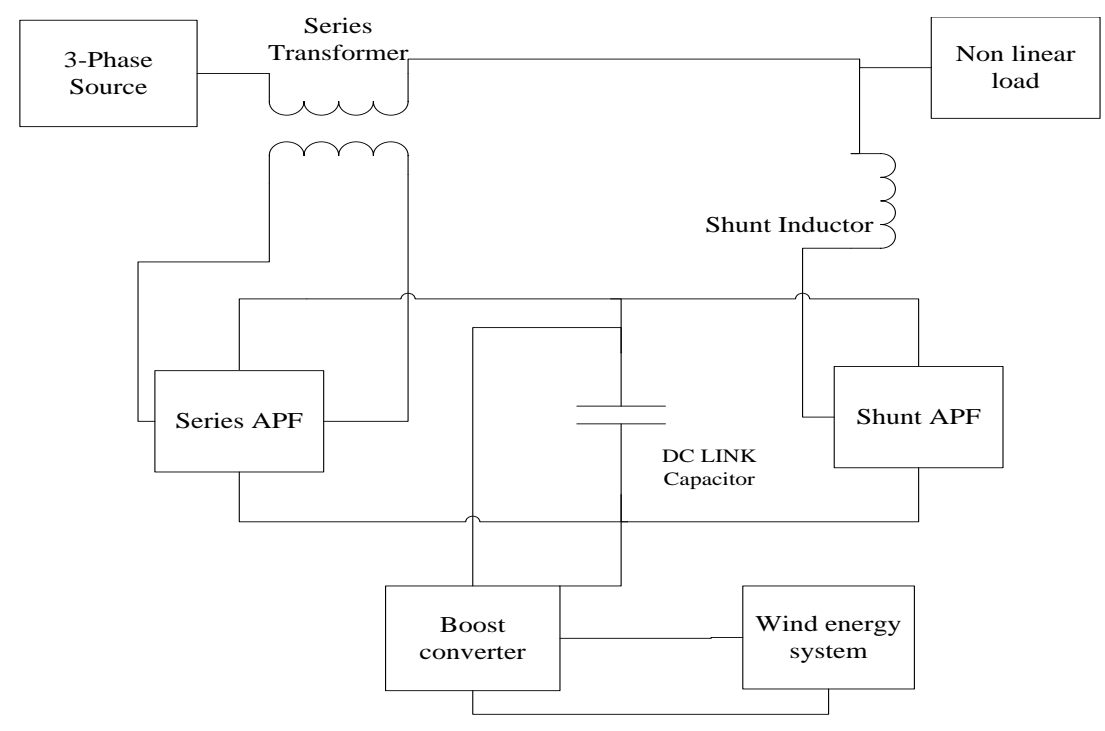

Figure 1. Basic block diagram for wind energy-UPQC system

\subsection{Wind Energy System}

The diagram shown in Figure 2 is the basic wind energy conversion system model. The wind kinetic energy first converted to rotational motion and by the use of gear box it is matches the speed of turbine and generator.

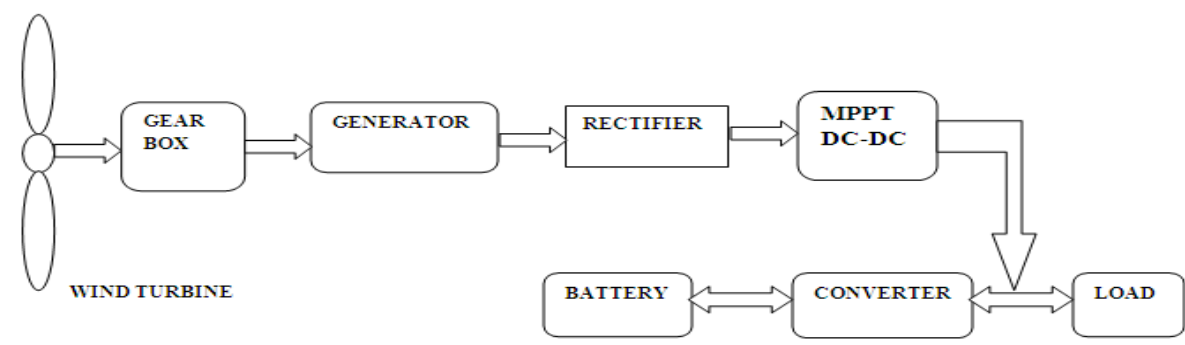

Figure 2. Wind energy system block diagram

The function of generator is to convert the mechanical energy of turbine to electrical energy. A rectifier is used to convert the AC voltage to DC and a battery is connected in such a way that it can charged both the way i.e a bidirectional converter is used to charge the battery [10-11].

\subsection{Modeling of Wind Turbines}

The kinetic energy of wind is converted to rotational motion i.e wind power to mechanical power conversion is done with the help of wind turbine blade in contact with wind speed. So different Equation 1 are given for power generation from wind [12-13]. 


$$
\begin{aligned}
& P m=\frac{1}{2} \pi \rho C p(\lambda, \beta) R^{2} V^{3} \\
& C_{p}=\frac{1}{2}\left(\frac{116}{\lambda_{1}}-0.4 \beta-5\right) \exp \frac{-165}{\lambda_{1}} \\
& \lambda_{1}=\left(\frac{1}{\frac{1}{\lambda+0.089}-\frac{0.035}{\beta^{3}+1}}\right)
\end{aligned}
$$

where; $\mathrm{P}_{\mathrm{M}}-$ Mechanical power, $\mathrm{r}$-Air density,b -Pitch angle, $\mathrm{R}$-Blade Radius-Speed of the wind $\lambda$ is the tip-speed ratio, given byl $=\mathrm{WR} / \mathrm{V}$

$\Omega$ - Rotor speed of rotation (in $\mathrm{rad} / \mathrm{sec}$ ) and $\mathrm{C}_{\mathrm{P}}$ can be expressed as the function of the tip-speed ratio $(\lambda)$.

$\mathrm{C}_{\mathrm{P}}$-Power coefficient of turbine and $\lambda_{1}-$ Any constant

The kinetic energy of the turbine is converted to mechanical energy and the turbine shaft is connected to rotor shaft of the generator. The power is transmitted from turbine to generator with the help of shaft. The generator rotor winding is known as armature which is rotates in between the magnetic stationary field and produce electrical voltage according to general generator principle.

In case of permanent magnet synchronous generator (PMSG) the magnetic field is stationary and the flux is produce by permanent magnet not by electromagnet, so a separate supply is not required for creation of magnetic field and the field flux remain constant. Another advantage of PMSG is that there is no requirement of slip ring. All other construction remains same as that of normal synchronous generator [14-16]. The simulation of wind turbine is shown in Figure 3 and the generator current, torque and current is shown in Figure 4.

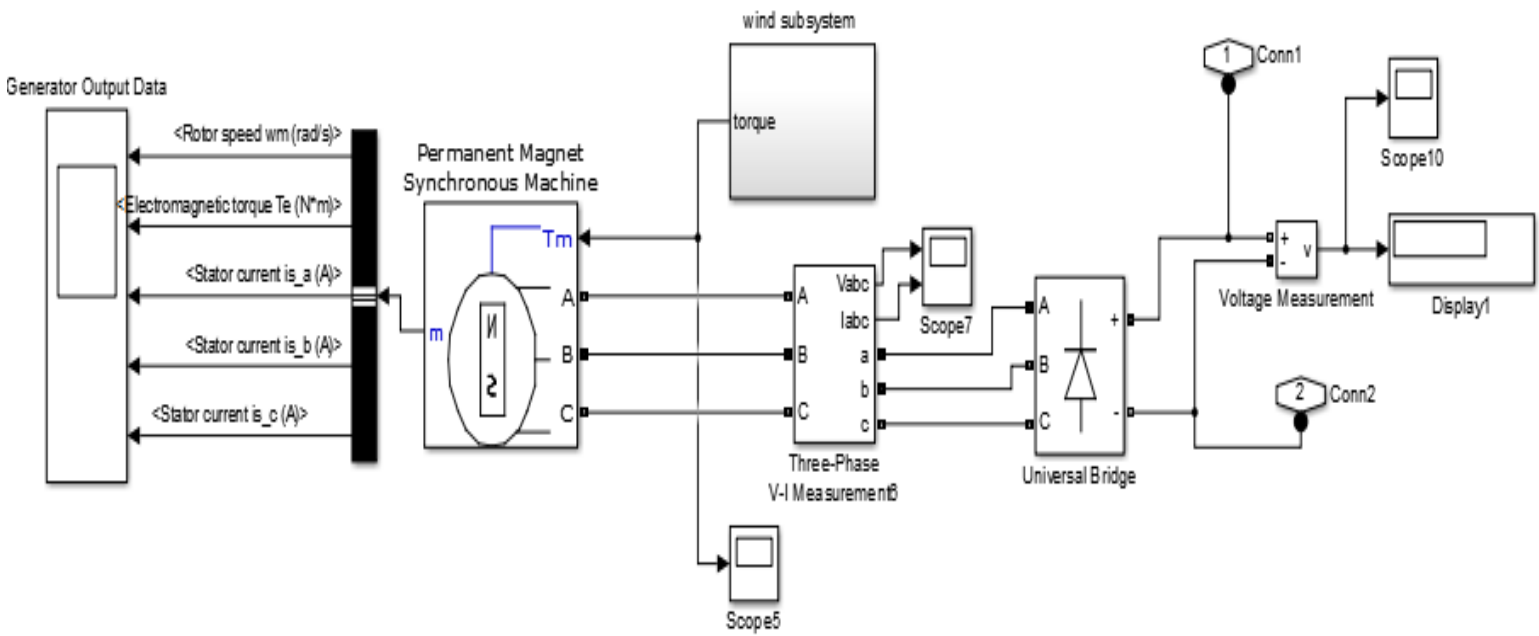

Figure 3. Simulation of wind system with PMSG and rectifier

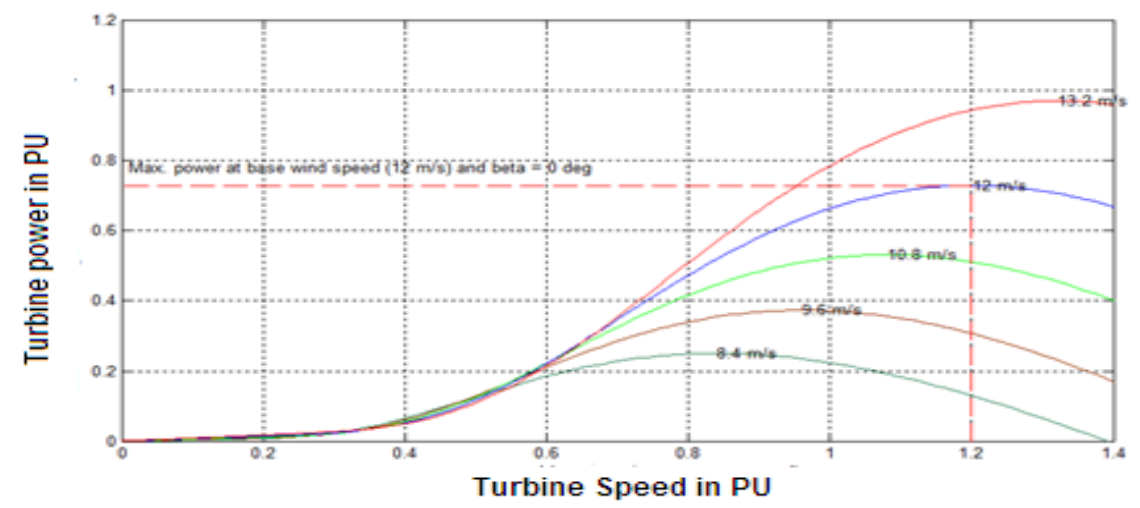

Figure 4. Simulation result of turbine speed vs power 


\subsection{DC to DC Boost Converter}

A step up DC/DC converter is a boost converterwhich increases the solar voltage to desired output voltage as required by load. The configuration is shown in Figure 5, which consists of an inductor $L$, switch $S$, diode $D_{1}$, capacitor $C$ for filter, load resistance R and DC input voltage Vin.

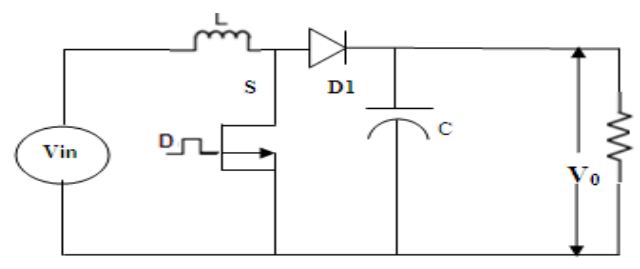

Figure 5. Basic circuit for boost converter

When the switch $\mathrm{S}$ is turned $\mathrm{ON}$ by using switching pulse the boost inductor stores the energy fed from the input voltage source and during this time the load current is maintain by the charged capacitor so that the load current should be continuous.

During the switch off period the input voltage and the stored inductor voltage will appear across the load hence the load voltage is increased

Hence, the load voltage is depending upon weather switch $\mathrm{S}$ in $\mathrm{ON}$ or OFF and this is depending upon the duty ratio D.

Science the switch conducts with a duty ratio $D$ and then the output DC voltage is given by Equation 5

$$
\frac{\mathrm{V}_{0}}{\mathrm{~V}_{\mathrm{s}}}=\frac{1}{1-\mathrm{D}}
$$

The minimum value of duty cycle $\mathrm{D}_{\min }$ and maximum value of duty cycle $\mathrm{D}_{\max }$ used for a lossless boost converter is given by the following equations;

$$
\mathrm{D}_{\max }=1-\frac{\mathrm{v}_{\mathrm{in}-\mathrm{min}}}{\mathrm{V}_{\mathrm{o}}} \times \eta
$$

Where, $\mathrm{D}_{\max }$ is the maximum duty ratio required to keep the converter in Continuous Conduction Mode (CCM)

$$
\mathrm{D}_{\min }=1-\frac{\mathrm{v}_{\mathrm{in} \_\max }}{\mathrm{v}_{\mathrm{o}}} \times \eta
$$

Where, $\mathrm{D}_{\min }$ is the minimum duty cycle required to keep the converter in $\mathrm{CCM}$

\section{CONTROL STRATEGIES OF THE UPQC SYSTEM}

There are several control strategies available to find out the reference values of the voltage and the current of UPQC. The Figure 6 shows the block diagram for control strategies of UPQC system. The concept of instantaneous active power $(p)$ and reactive power $(q)$ and its application in shunt filter reference current generation, the synchronous reference frame theory, the fuzzy logic control (FLC) for the control of UPQC method are some of the above mentioned control strategies. Based on the above discussion, $d-q$ theory with hysteresis current control mode is suitable for parallel mode operation of UPQC system and $d-q$ theory with PWM voltage control mode is suitable for interruption mode operation. The hysteresis control method is simple to implement and it has enhanced system stability, increased reliability and mitigates power quality problems.

UPQC consists of two main controllers as follows:

a. Series Active Power Filter

b. Shunt Active Power Filter 


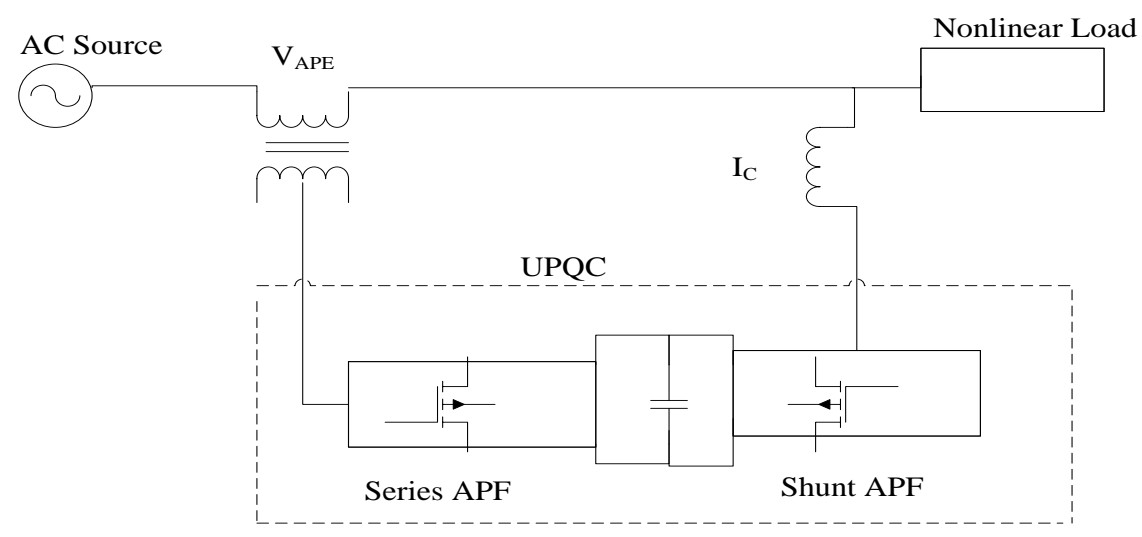

Figure 6. Block diagram of UPQC

\subsection{Control Scheme of Series Active Filter}

The block diagram for series APF control scheme is shown in Figure 7 where Park's transformation method is used for generation of unit vector signal. The actual voltage and the reference are converted to $d q 0$ from $a b c$ coordinates and both are compared in $d q 0$ reference frame. After the comparison both are again converted to $a b c$ reference frame. From PLL (phase locked loop) $\varnothing$ can be generated which is required for Park's transformation and inverse Park's transformation. The switching pulses required for VSI conduction are generated from the comparison of selected output voltage $\left(\mathrm{Vc}^{*}\right)$ with the sensed series APF output voltage $(\mathrm{Vc})$ in a hysteresis voltage controller.

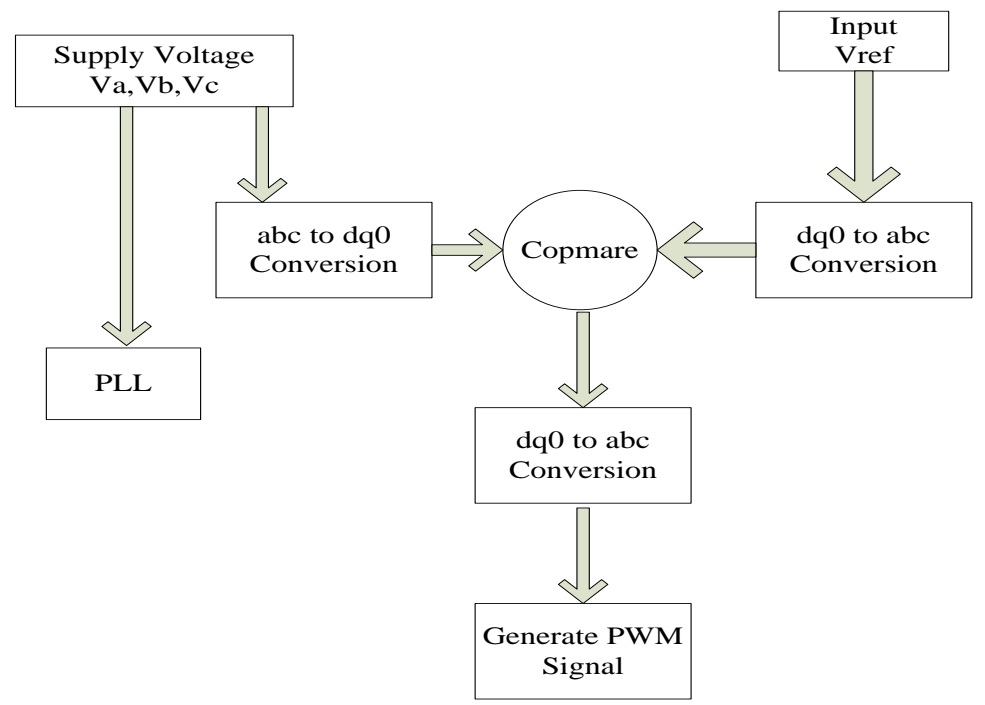

Figure 7. Block diagram for control scheme of series active filter

\subsection{Control Scheme for Shunt Active Power Filter}

The shunt (APF) is normally connected in parallel to the system which indicates the harmonics content. To eliminate the harmonics, the equal amount of harmonic compensating current is injected in opposite phase w.r.t the harmonic current. The control scheme shown in Figure 8 includes the transfer of source current from $a-b-c$ to $d-q$ frame. In nonlinear load the source current includes both oscillating as well as dc component. The dc component is only positive sequence component but the oscillating component includes positive, negative and zero sequence components. To maintain the DC link voltage this active filter will absorb some active power from the power system. The shunt active filter eliminates the harmonics component present in the source current $\&$ make the source current wave form pure sinusoidal by acting as a current controlled voltage source inverter. 


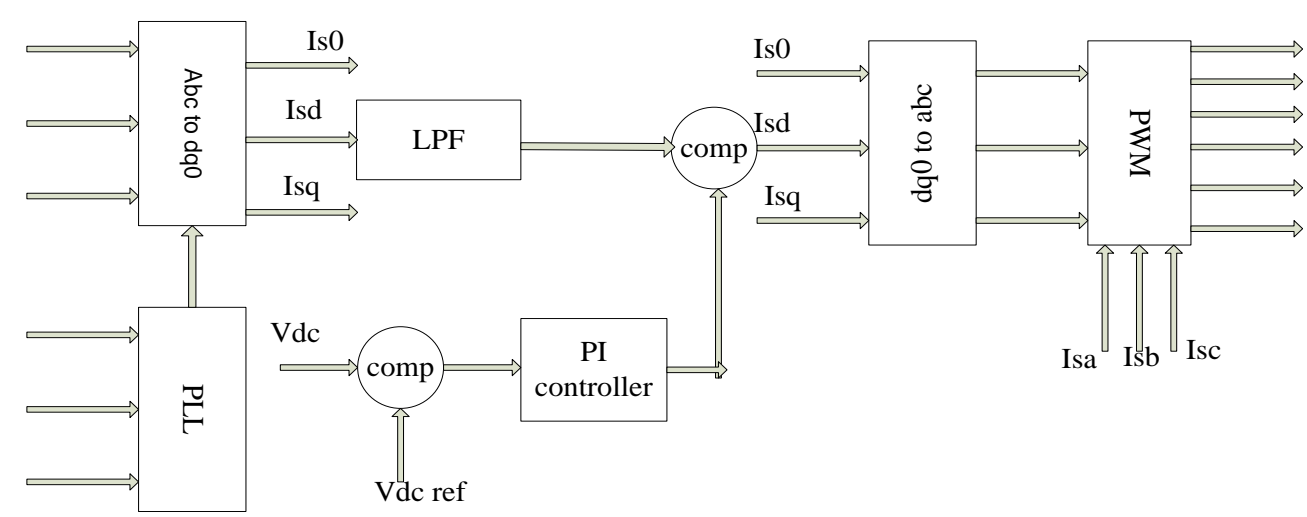

Figure 8. Block diagram for control scheme of shunt active power filter

\subsection{Design of Shunt APF}

a. DC link capacitor:-The active and reactive power flow to the system is provided by the link capacitor when it is required.

b. Voltage source inverter: The electronics device which converts direct current to alternating current when PWM signal is given to the gates of its IGBT or GTO etc. Here the main function of the VSI is to compensate the source current harmonics present by injecting the equal and opposite compensating current to the system.

c. Hysteresis Current Controller: -Hysteresis current controller shown in Figure 9 generates PWM signal by comparing the reference signal w.r.t to the actual signal the figure shows the generation of PWM signal by comparing the two current signals.

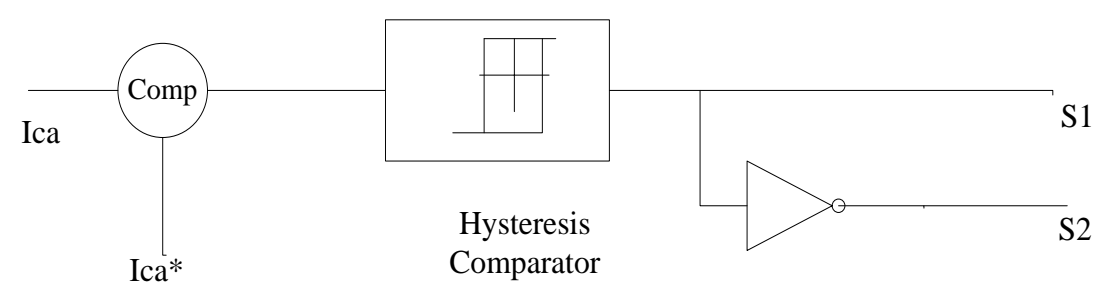

Figure 9. Principle of hysteresis current controller

\section{RESULT AND DISCUSSION}

The Simulink models of wind energy-UPQC are simulated in Matlab which is shown in Figure 10 which consist of series APF, shunt APF, wind energy and boost converter. The simulation result shown in Figure 11 is without series filter where voltage sag is clearly shown from $0.1 \mathrm{sec}$. to $0.3 \mathrm{sec}$. Injected values shown in Figure 12. The load voltage is compensated to actual value as shown in Figure 13. The Figure 14 shows the simulation result load current before compensation and Figure 15 shows the harmonics content i.e. $16.6 \%$ by using FFT analysis. When the shunt active filter injects current from $0.1 \mathrm{sec}$.to $0.4 \mathrm{sec}$ as shown in Figure 16. The load current harmonics is reducing to $2.33 \%$ as shown in the FFT analysis Figure 18 for which the load current is nearly sinusoidal as shown in Figure 17. 


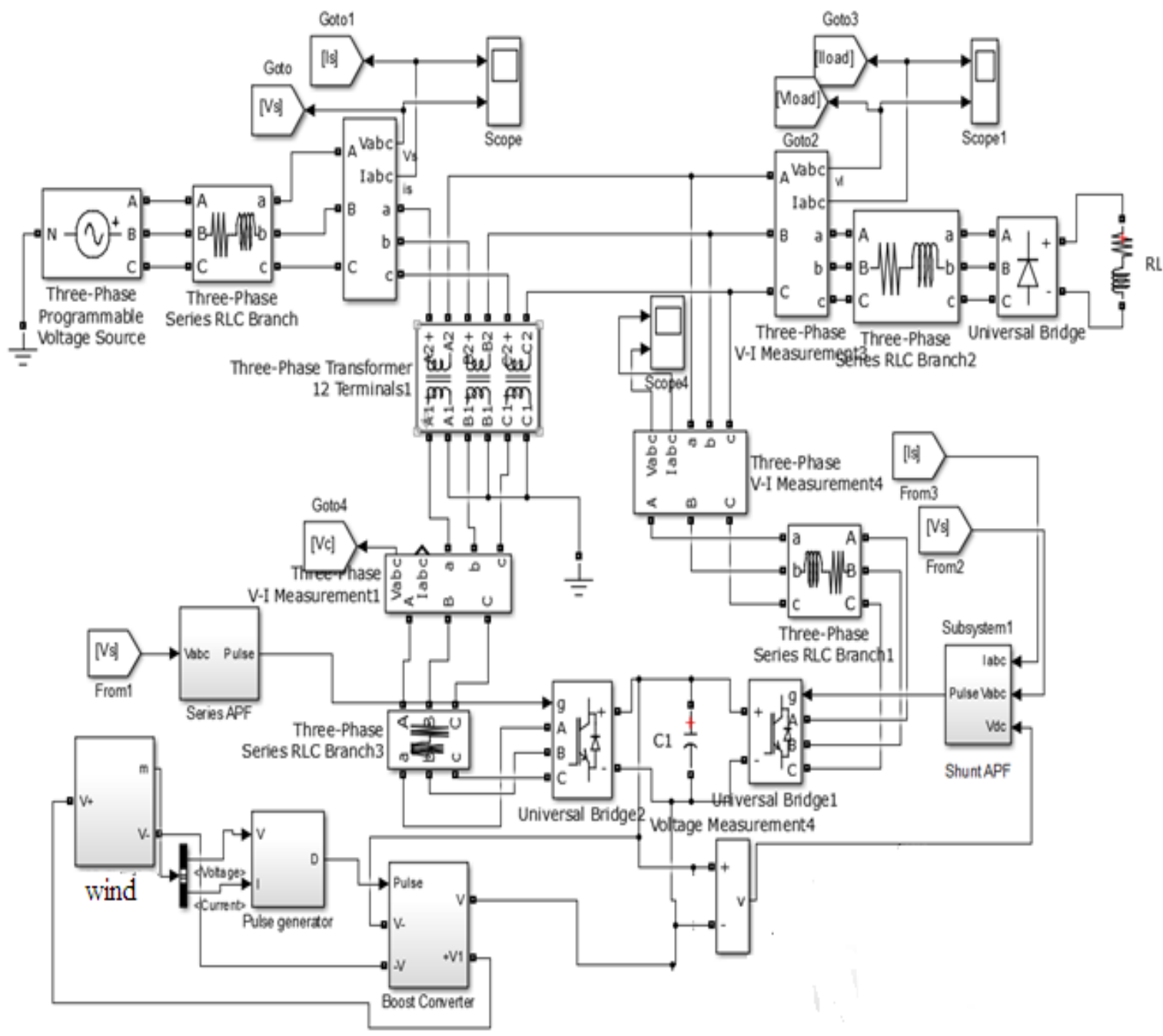

Figure 10. Simulation of wind-UPQC system

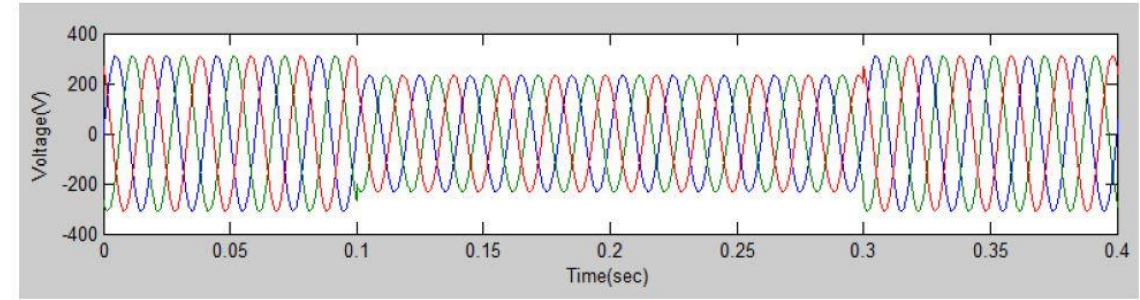

Figure 11. Load voltage without series active filter

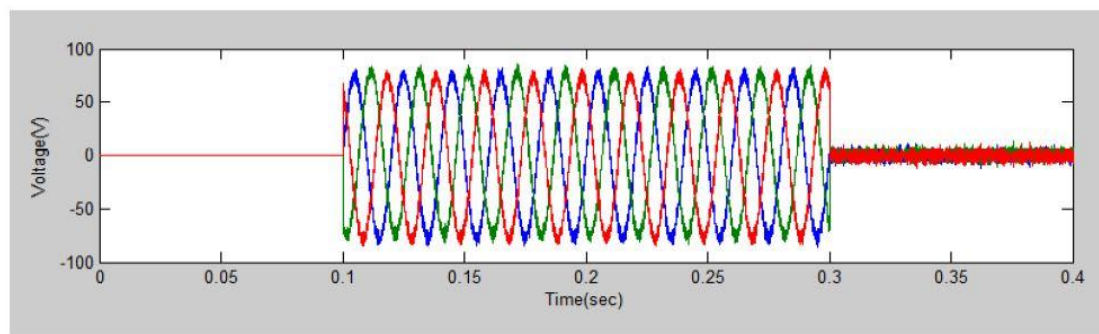

Figure 12. Injected voltage 


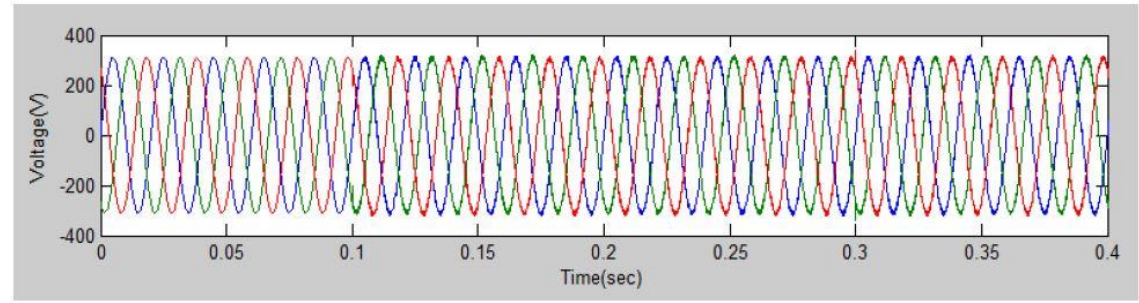

Figure 13. Load voltage with series active filter

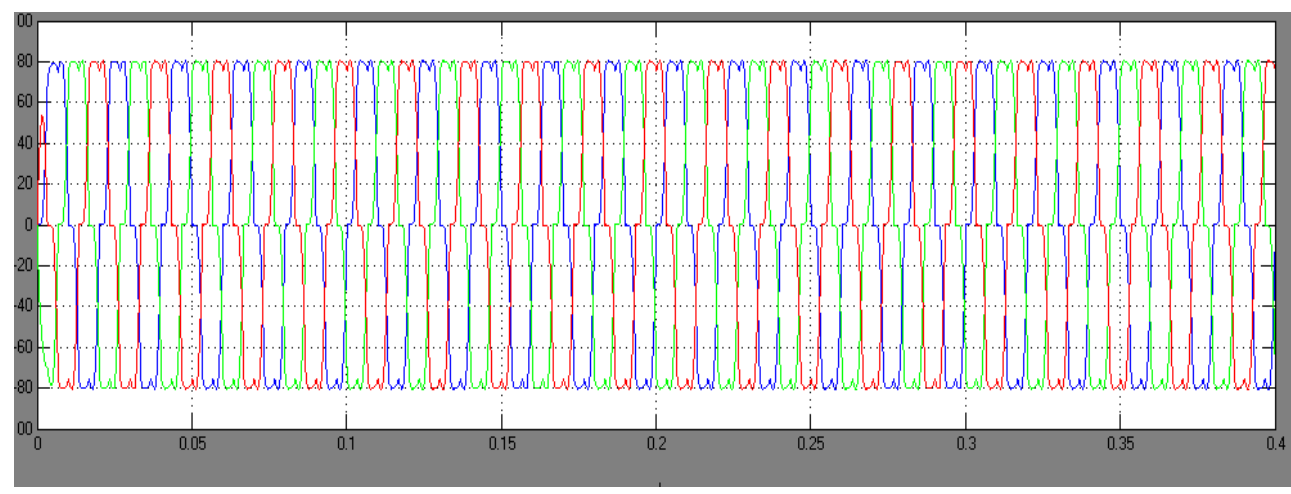

Figure 14. Load current before compensation

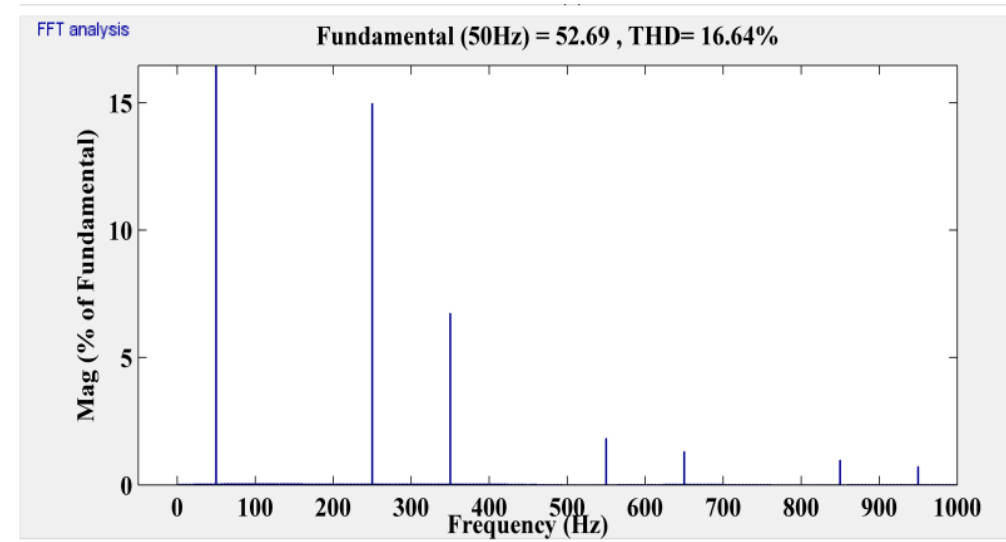

Figure 15. Harmonics analysis without shunt APF

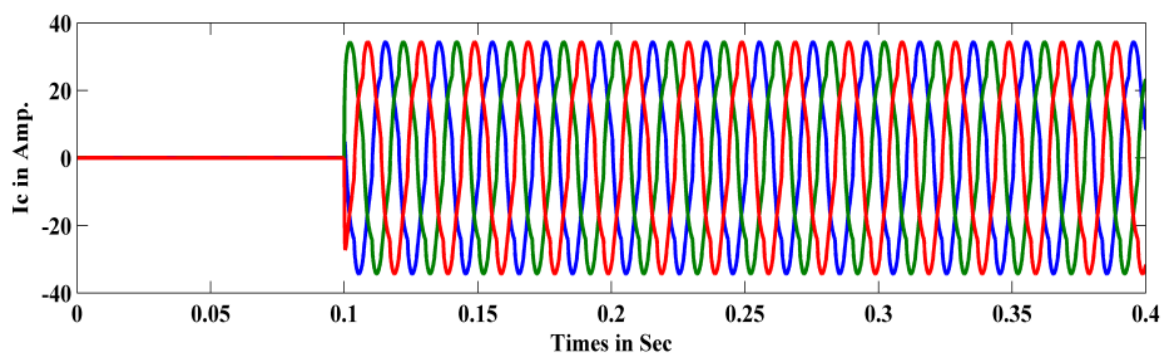

Figure 16. Current Injected by shunt active filter 


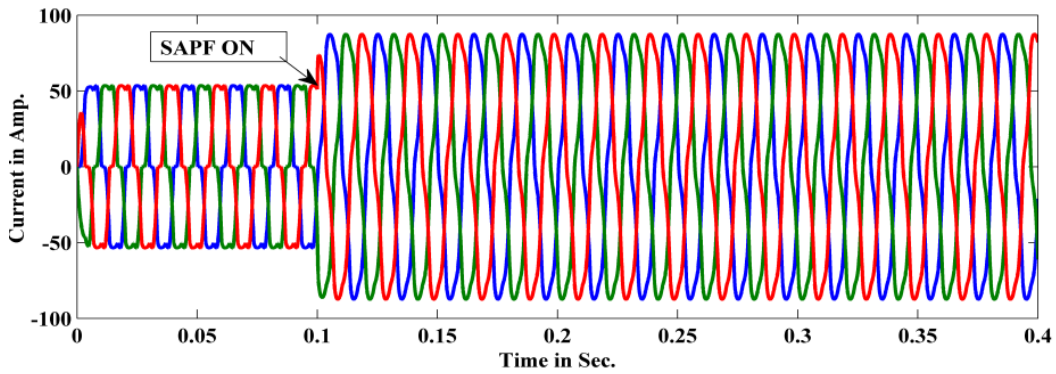

Figure 17. Load current with shunt APF

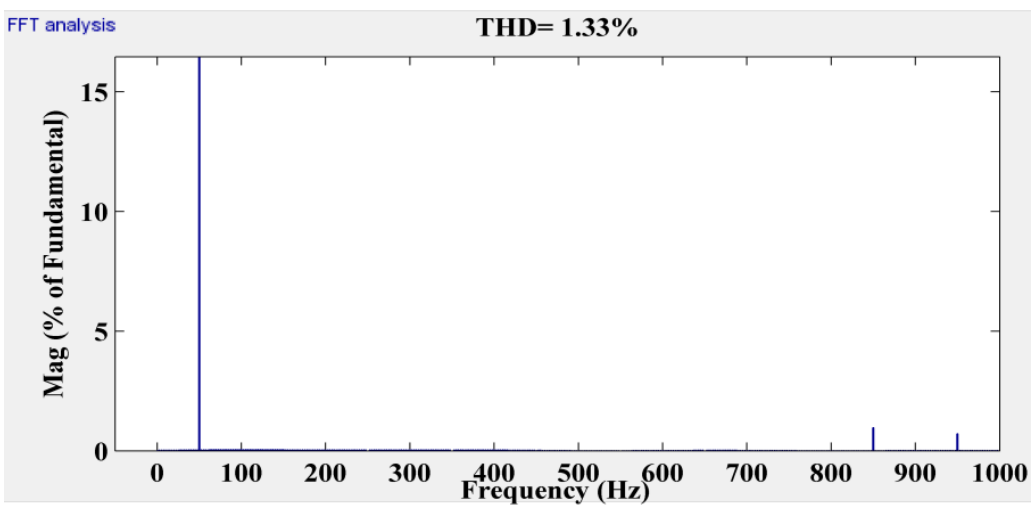

Figure 18. Harmonics analysis with shunt APF

\section{CONCLUSION}

The advantage of wind energy system is to retain a constant voltage of 600 volts across the DC-Link capacitor. In this work the wind energy with boost converter output is $600 \mathrm{~V}$ and simulation of wind energyUPQC maintains constant voltage of $600 \mathrm{~V}$ when Sag, Swell and Interruption occur. It also reduces the harmonics content to $2.33 \%$ if any nonlinear load is associated as shown in Figure 19. Hence the proposed scheme can regulate active and reactive power injection to the grid and compensate voltage sag and swell in addition to the other usual operation of UPQC effectible as the voltage across the dc link capacitor is maintained constant. Figure 20 shows DC link voltage.

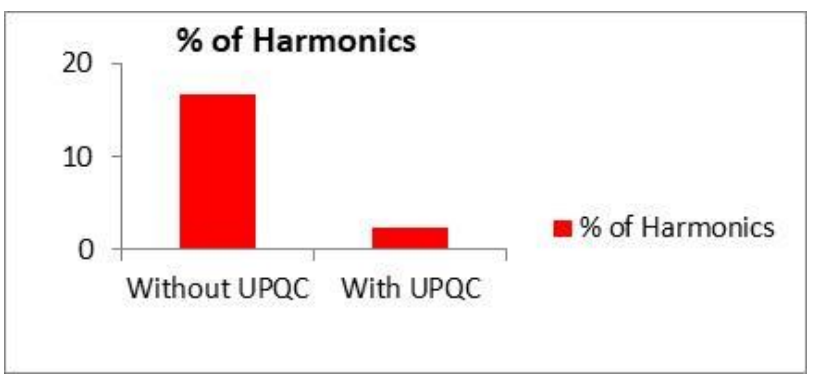

Figure 19. Harmonic analysis comparision

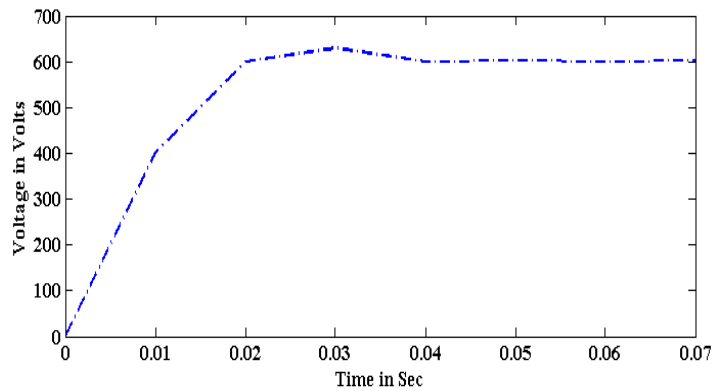

Figure 20. DC-link voltage

\section{REFERENCES}

[1] Carrasco JM, Franquelo LG, Bialasiewicz JT, Galván E, PortilloGuisado RC, Prats MM, León JI, Moreno-Alfonso N. Power-electronic systems for the grid integration of renewable energy sources: A survey. IEEE Transactions on industrial electronics. 2006; 53(4): 1002-1016.

[2] Samal S, Hota PK. Power Quality Improvement by Solar Photo-voltaic/Wind Energy Integrated System Using Unified Power Quality Conditioner. International Journal of Power Electronics and Drive Systems (IJPEDS). 2017; 8(3): 1424. 
[3] Samal S, Hota PK. Power Quality Improvement by Solar Photo-voltaic/Fuel Cell Integrated System Using Unified Power Quality Conditioner. International Journal of Renewable Energy Research (IJRER). 2017; 7(4): 2075-84.

[4] Samal S, Hota PK. Design and analysis of solar PV-fuel cell and wind energy based microgrid system for power quality improvement. Cogent Engineering. 2017; 4(1): 1402453.

[5] Basu M, Das SP, Dubey GK. Comparative evaluation of two models of UPQC for suitable interface to enhance power quality. Electric Power Systems Research. 2007; 77(7): 821-830.

[6] Montero MI, Cadaval ER, Gonzalez FB. Comparison of control strategies for shunt active power filters in threephase four-wire systems. IEEE transactions on power electronics.2007; 22(1): 229-236.

[7] Lee GM, Lee DC, Seok JK. Control of series active power filters compensating for source voltage unbalance and current harmonics. IEEE Transactions on industrial electronics. 2004; 51(1): 132-139.

[8] Fitzer C, Barnes M, Green P. Voltage sag detection technique for a dynamic voltage restorer. InIndustry Applications Conference, 2002. 37th IAS Annual Meeting. Conference Record of the 2002 Oct 13; 2: 917-924.

[9] Jain SK, Agarwal P. Design simulation and experimental investigations, on a shunt active power filter for harmonics, and reactive power compensation. Electric Power Components and Systems. 2003 Jul 1; 31(7):671-92.

[10] Altas IH, Sharaf AM. A photovoltaic array simulation model for matlab-simulink GUI environment. InClean Electrical Power, 2007. ICCEP'07. International Conference on 2007; 341-345.

[11] Rolan A, Luna A, Vazquez G, Aguilar D, Azevedo G. Modeling of a variable speed wind turbine with a permanent magnet synchronous generator. InIndustrial Electronics, IEEE International Symposium on 2009 Jul 5, 734-739.

[12] Tafticht T, Agbossou K, Cheriti A, Doumbia ML. Output power maximization of a permanent magnet synchronous generator based stand-alone wind turbine. InIndustrial Electronics, 2006, IEEE International Symposium on 2006 Jul 9; 3, 2412-2416.

[13] Rahmani S, Hamadi A, Ndtoungou A, Al-Haddad K, Kanaan HY. Performance evaluation of a PMSG-based variable speed wind generation system using maximum Power Point Tracking. InElectrical Power and Energy Conference (EPEC), 2012; 223-228.

[14] Zhang S, Tseng KJ, Vilathgamuwa DM, Nguyen TD, Wang XY. Design of a robust grid interface system for PMSG-based wind turbine generators. IEEE transactions on industrial electronics. 2011; 58(1): 316-328.

[15] Baroudi JA, Dinavahi V, Knight AM. A review of power converter topologies for wind generators. Renewable energy, Elsevier, 2007; 32(14): 2369-2385.

[16] Abdullah MA, Yatim AH, Tan CW, Saidur R. A review of maximum power point tracking algorithms for wind energy systems. Renewable and sustainable energy reviews. 2012; 16(5): 3220-3227. 